\title{
Determinants in the adoption of total quality management (tqm) in the construction sector: a management perspective.
}

\author{
Determinantes de la adopción de la gestión de la calidad total (gct) en el sector de la \\ construcción desde la perspectiva de la gestión empresarial
}

\author{
Javier García-Bernal (Main Author) \\ Universidad de Zaragoza, Facultad de Economía y Empresa \\ jgbernal@unizar.es \\ Nieves García-Casarejos (Contact Author) \\ Universidad de Zaragoza, Facultad de Economía y Empresa \\ Gran Vía, 2. 50005 Zaragoza (Spain),+34 976761782/ +34 876554691 \\ ngarcia@unizar.es
}

Manuscript Code: 477

Date of Acceptance/Reception: 01.08.2016/06.10.2014

\begin{abstract}
:
Although the empirical evidence shows the existence of a positive relationship between the adoption of TQM and an improvement in corporate performance, its dissemination is heterogeneous among companies in the construction sector. The main objective of this paper focuses on identifying the relevant factors that drive executives of construction companies to adopt TQM. Specifically, it analyzes the extent to which company managers' expectations of the impact of TQM on their business performance determine whether they will adopt TQM or not. The results show that expectations concerning financial improvement, environmental issues, and the satisfaction of customers and employees drive company managers in the construction sector to adopt TQM.
\end{abstract}

Keywords: Total Quality Management (TQM), organizational innovation, business performance, CEO's expectations, level of implementation of TQM.

\section{Resumen:}

Aunque la evidencia empírica muestra la existencia de una relación positiva entre adopción de la Gestión de calidad total (GCT) y una mejora en el desempeño organizativo, el nivel de difusión es desigual entre las empresas del sector de la construcción. El principal objetivo del presente trabajo es identificar los factores relevantes que impulsan a los directivos de las empresas de la construcción a adoptar la GCT. Específicamente, analiza el grado al cual las expectativas de los gerentes de las empresas sobre los efectos del GCT en el desempeño de su negocio determinan si es que ellos adaptaran GCT o no. Los resultados muestran que las expectativas relativas a la mejora financiera, las cuestiones ambientales, y la satisfacción de los clientes y los empleados conducen a los directivos de las empresas del sector de la construcción a adoptar GCT.

Palabras clave: Gestión de calidad total (GCT), innovación organizacional, rendimiento del negocio, expectativas del CEO, nivel de implementación de la GCT.

\section{Introduction}

The construction sector has been affected negatively by the current recession and demand has shrunk significantly. Nonetheless, the sector has undergone numerous innovations in both construction and organization since the end of the nineties, which include the adoption of management systems based on the principles and practices of Total Quality Management (TQM). However, the spread of TQM has not followed a homogenous pattern in the construction sector, and there is a relatively high number of companies that do not intend to adopt TQM. Consequently, the construction sector is still not in line with the management standards of other industrial sectors that started to implement TQM systems decades ago (for example the automobile industry).

Many academic papers have highlighted the positive relationship between adopting TQM and improved business performance. The most recent include articles by Corredor \& Goñi (2011) and Duh, Hsu \& Huang (2012). There is, therefore, an opportunity for construction companies to improve their business performance by improving their management systems, but numerous companies are still not taking advantage of this opportunity. In other words, there is a relatively high number of companies in the construction sector that do not believe that adopting TQM is necessary, despite the potential benefits it can bring. In the literature specialized in TQM there are very few papers focusing on explaining this circumstance. One exception is the work by García-Bernal \& García-Casarejos (2014), which establishes that the unbalanced use of TQM in the business world might be due to the fact that the potential of TQM to generate wealth depends on the company's size and the subsector it operates in. Specifically, the authors argue how TQM's capacity to add value is more in larger companies operating in subsectors with a presence of high levels of specific knowledge. The empirical results of their work show that it is the companies with these characteristics that 
are more likely to adopt TQM since the potential increases in the levels of wealth created are greater. As Arriagada \& Alarcón (2013) point out, construction companies are knowledge-intensive firms that are very dependent on their workers' skills.

But what do the managers think about the real potential of TQM to improve their companies' performance? The main objective of this paper is to explore this question further by focusing on identifying how construction company managers' differing expectations of the impact of TQM on their business performance determine whether they will adopt TQM or not. Therefore, we aim to ascertain the specific expectations that finally drive construction company managers to adopt TQM on the assumption that not all business performance indicators will be equally relevant.

The paper is structured as follows to achieve the research objectives. The next section contains a discussion and presentation of various hypotheses on how higher or lower business expectations can condition the high or low level of implementation of TQM. The third section includes the empirical analyses to test the proposed hypotheses. Finally, the last of the sections synthesizes the main conclusions and business implications arising from the research work.

\section{Total quality management (tqm) and business performance}

Total Quality Management (TQM) is an organizational option that allows companies to efficiently manage coordination problems by delegating the business owners' authority to the people that have the relevant information to make decisions (García-Bernal \& García-Casarejos, 2014; García-Bernal \& Ramírez-Alesón, 2010; Wruck \& Jensen, 1994). Following these authors, optimal level of TQM adoption depends on TQM Direct Costs and Residual Losses (see figure 1). In this context, this paper focuses on analyzing the extent to which managers' expectations of the impact of TQM on their business performance determine the construction company's level of implementation of TQM.

Figure 1. Optimum level of TQM adoption. Source: García-Bernal \& García-Casarejos, 2014

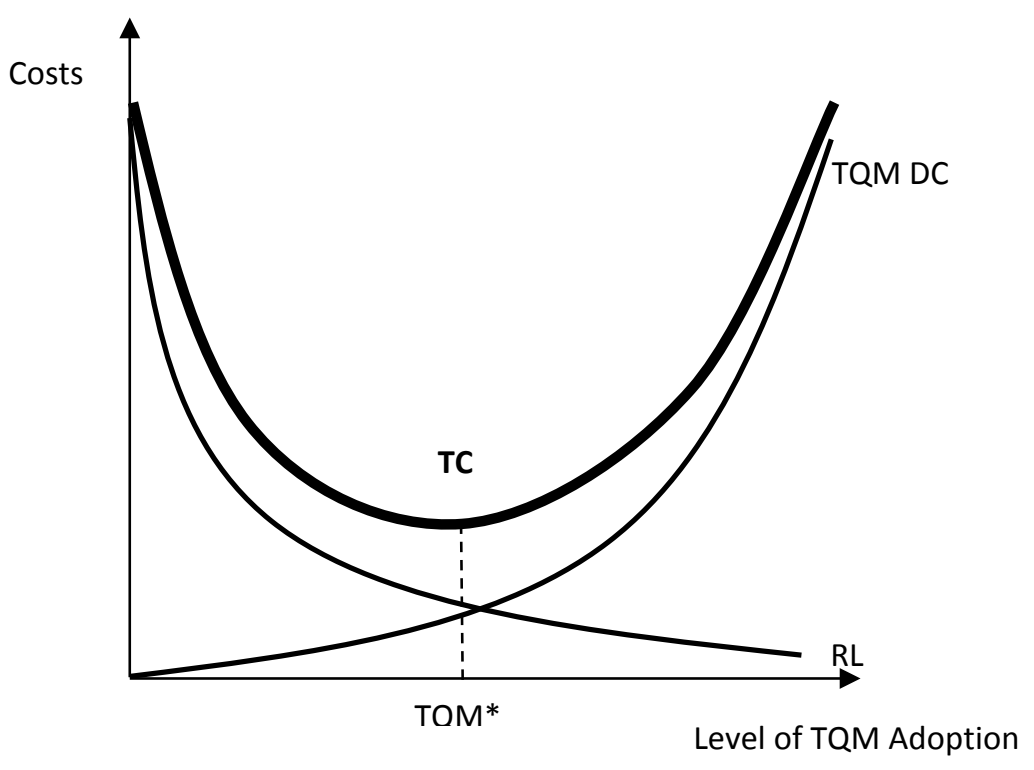

The literature on the relationship between TQM and business performance is extensive. The potential benefits of TQM have been analyzed from various analysis perspectives (García-Bernal \& Ramírez-Alesón, 2015). Some research has adopted an internal perspective by analyzing the impact of TQM on improving the indicators directly related to operational efficiency (Flynn, Sakakibara \& Schroeder, 1995). Other research, with an external perspective, has linked TQM to an improvement in customer satisfaction levels (Anderson, Rungtusanatham, Schroeder \& Devaraj, 1995). There are also papers that have directly analyzed the relationship between adopting TQM and an improvement in financial indicators (Hendricks \& Singhal, 2001). And finally, other papers have also analyzed how TQM impacts on the levels of satisfaction of other non-financial groups, such as workers (Samson \& Ford, 2000) and society (Bou-Llusar, Escrig-Tena, Roca-Puig \& Beltrán-Martín, 2009). Following García-Bernal \& Ramírez-Alesón (2015), all these perspectives are simultaneous illustrated in figure 2. 


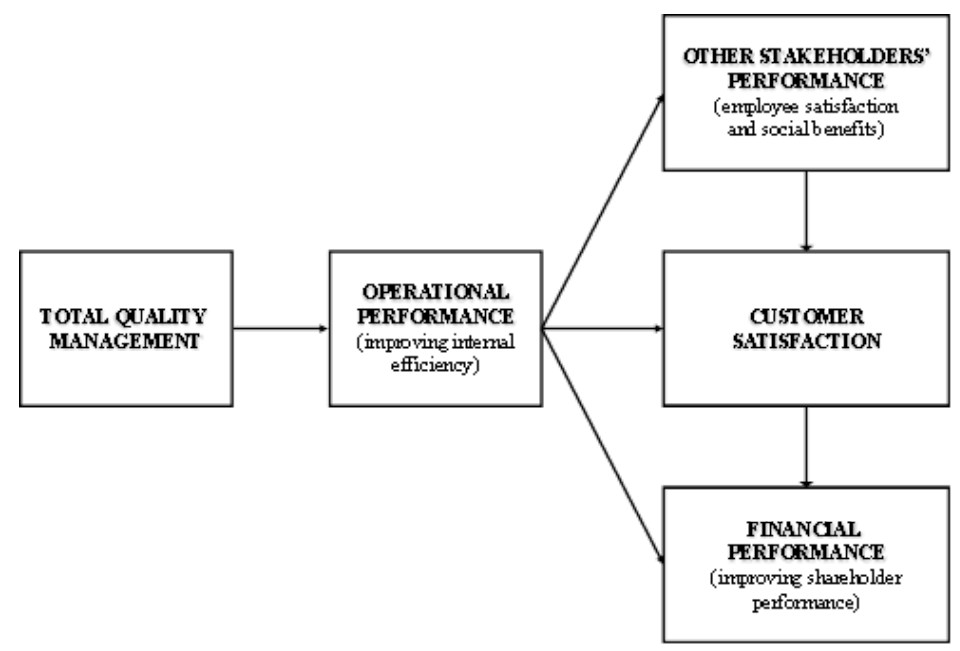

With reference to the impact of TQM on improving internal efficiency indicators, several papers analyze specific aspects that can improve as a result of adopting TQM. Some authors (Rubio-Andrada, Alonso-Almeida \& RodriguezAnton, 2011) analyze how TQM has a positive effect on reducing overall costs. Sila \& Ebrahimpour (2005) analyze how TQM has a positive impact on reducing production times. Finally, some research (Mann, Adebanjo, Laosirihongthong \& Punnakitikashem, 2011) analyze how TQM has a positive impact on improving productivity. The above-mentioned aspects can all improve when TQM is implemented; companies can consider whether to adopt TQM or not based on their managers' expectations of the system improving these aspects. Three hypotheses were proposed for testing:

Hypothesis 1: Companies whose managers have higher expectations of the impact of TQM on reducing overall costs will adopt TQM to a greater extent.

Hypothesis 2: Companies whose managers have higher expectations of the impact of TQM on reducing production times will adopt TQM to a greater extent.

Hypothesis 3: Companies whose managers have higher expectations of the impact of TQM on increasing productivity will adopt TQM to a greater extent.

With reference to the impact of TQM on improving financial indicators, several papers analyze aspects that can improve as a result of adopting TQM. Some authors (Rao, Solis \& Raghunathan, 1999) analyze the impact of TQM on maintaining the company's current business. Other authors (Escrig-Tena \& Bou-Llusar, 2005; Sila \& Ebrahimpour, 2005) analyze the impact of TQM on an increase in earnings. Finally, there are studies (Powell, 1995; Sila \& Ebrahimpour, 2005) that analyze the impact of TQM on improving the company's competitive position. All the abovementioned aspects can improve when TQM is implemented, and company managers can consider whether to adopt TQM or not based on their expectations of the system improving these aspects. Therefore, another three hypotheses were proposed for testing:

Hypothesis 4: Companies whose managers have higher expectations of the impact of TQM on maintaining current business will adopt TQM to a greater extent.

Hypothesis 5: Companies whose managers have higher expectations of the impact of TQM on increasing earnings will adopt TQM to a greater extent.

Hypothesis 6: Companies whose managers have higher expectations of the impact of TQM on improving their competitive position will adopt TQM to a greater extent.

The above-mentioned financial indicators state the interests of financial groups, in other words the company's owners or shareholders. However, adopting TQM also affects the level of satisfaction of non-financial groups, such as customers (Wilson \& Collier, 2000), employees (Taylor \& Wright, 2006) and society or the community surrounding the company (Lai \& Cheng, 2003). Therefore, the interest of these non-financial groups can improve when TQM is implemented, and company managers can consider whether to adopt TQM or not based on their expectations of the 
system improving the level of satisfaction of the above-mentioned groups. Therefore, another additional three hypotheses were proposed for testing:

Hypothesis 7: Companies whose managers have higher expectations of the impact of TQM on improving their customers' level of satisfaction will adopt TQM to a greater extent.

Hypothesis 8: Companies whose managers have higher expectations of the impact of TQM on improving their employees' level of satisfaction will adopt TQM to a greater extent.

Hypothesis 9: Companies whose managers have higher expectations of the impact of TQM on improving their community's level of satisfaction will adopt TQM to a greater extent.

The impact of the company's business on environmental aspects is directly related to the community's level of satisfaction. Therefore, besides analyzing the effects of adopting TQM on reducing the waste levels generated (Adam, 1994), company managers can also promote the implementation of TQM to reduce incidents that have a negative effect on the environment. Consequently, another two hypotheses were proposed:

Hypothesis 10: Companies whose managers have higher expectations of the impact of TQM on reducing waste levels generated will adopt TQM to a greater extent.

Hypothesis 11: Companies whose managers have higher expectations of the impact of TQM on reducing incidents that have a negative effect on the environment will adopt TQM to a greater extent.

Finally, to broaden the sphere of non-financial groups that can be affected by adopting TQM, and whose levels of satisfaction can condition the implementation of TQM to a greater or lesser extent, the last three hypotheses were proposed:

Hypothesis 12: Companies whose managers have higher expectations of the impact of TQM on improving their suppliers' level of satisfaction will adopt TQM to a greater extent.

Hypothesis 13: Companies whose managers have higher expectations of the impact of TQM on improving the level of satisfaction of public administrations will adopt TQM to a greater extent.

Hypothesis 14: Companies whose managers have higher expectations of the impact of TQM on improving the level of satisfaction of non-profit organizations and other activists will adopt TQM to a greater extent.

Empirical analysis

\section{Description of the Sample}

Information on a sample of construction companies in the Spanish Autonomous Community of Aragon was to test the proposed hypotheses. Primary information sources were employed, since there was a lack of secondary data for a detailed analysis of the level of implementation of TQM in the construction sector in Aragon. This industry was deemed appropriate for a detailed analysis of the spread of TQM within it as it was one of the main drivers of economic growth in Spain until the current recession started. Specifically, the sector represented almost $11 \%$ of the gross domestic product of Aragon and employed over eighty thousand people. According to the latest report produced by the Aragonese Employment Agency, INAEM, (Construction Employment Foundation of Aragon, 2010), the sector's growth began to slow down in the first months of 2007, and the number of workers in the sector plummeted by over fourteen thousand workers. The crash continued, evidenced by the fact that in 2013 the number signed on with social security as workers fell by $20 \%$ compared with 2012 data (ISSLA, the Aragonese Agency of Occupational Health and Safety, 2013).

To obtain the necessary information to meet the research objectives, academic personnel with experience in research designed a questionnaire together with professional personnel specialized in TQM and the EFQM Excellence Model. Once designed it was validated by a group of experts that were not connected with the research. Information was collated using a postal questionnaire and later consolidated with personal interviews and telephone questionnaires. In total there is detailed information on 293 Aragonese companies, which were formed into a sample, stratified by size and province, and which is representative of the Aragonese population. The information collation process took almost all of the second half of 2008. As the rate of response to the first round of postal questionnaires was insufficient, a 
second round was necessary based on personal interviews and/or telephone questionnaires. This considerably increased the rate of response. The datasheet on the study is synthesized in Table 1.

Table 1. Datasheet. Source: Own Elaboration

\begin{tabular}{ll}
\hline Identification & Questionnaire on the adoption of TQM in construction companies in Aragon. \\
\hline Scope & Autonomous Community of Aragon \\
\hline Universe & Construction companies operating in the Autonomous Community of Aragon with at least 10 workers. \\
\hline Population (size) & 1,156 companies \\
\hline Instrument to obtain information & Postal questionnaire consolidated with personal interview or telephone questionnaire. \\
\hline Fieldwork dates & From 1 July 2008 to 23 December 2009. \\
\hline Completed questionnaires & 295 questionnaires \\
\hline Response rate & $25.5 \%$ \\
\hline Valid questionnaires & 293 questionnaires \\
\hline Confidence level & $95.5 \%$, with $\mathrm{p}=\mathrm{q}=0.5$. \\
\hline Sample error & $\pm 4.9 \%$ \\
\hline
\end{tabular}

Concerning the companies forming the sample, $68.9 \%$ are located in the province of Saragossa, approximately $21.5 \%$ are located in the province of Huesca, while the rest (9.6\%) are companies in Teruel. Regarding distribution by size, based on the classification established by the European Commission (6 May 2003 European Commission recommendation) which uses the number of workers as a basis, large companies represent $2 \%$ of the sample, while the rest are SMEs. Specifically, $15.4 \%$ are medium-sized companies and $82.6 \%$ are small companies. Micro-companies were not studied as it is difficult for TQM to generate value in them as there are so few employees. This means that the potential negative consequences arising from information or coordination problems are not very relevant. Finally, concerning the specific subsector in which each company performs the majority of their productive activities, almost $40 \%$ of the companies are specialized in the construction of buildings and just over $21 \%$ focus their activities in the subsector of specialized construction activities. The companies focusing their business on civil engineering make up $13 \%$ of the total companies, while only just over $7 \%$ perform their activities mainly in the ancillary activities subsector. The other companies diversify into two or more subsectors, although over $80 \%$ of them perform part of their business in the building construction subsector. Finally, approximately $95 \%$ of the companies state that they have a high level of independence or autonomy in management, while the others are restricted in their decision-making as they are subsidiaries of other companies in the majority of the cases.

Level of Implementation of Total Quality Management (TQM)

\begin{tabular}{|c|c|c|c|c|c|}
\hline & $N$ & $\%$ & $\mathbf{N}$ & $\%$ & \\
\hline Not planned & 146 & 49.8 & 146 & 49.8 & $\begin{array}{l}\text { Not planning to } \\
\text { implement TQM }\end{array}$ \\
\hline Planned long-term & 13 & 4.4 & \multirow{3}{*}{34} & \multirow{3}{*}{11.6} & \multirow{3}{*}{$\begin{array}{c}\text { Planning to } \\
\text { implement TQM } \\
\text { but not begun }\end{array}$} \\
\hline Planned medium-term & 14 & 4.8 & & & \\
\hline Planned short-term & 7 & 2.4 & & & \\
\hline Being implemented & 8 & 2.7 & \multirow{3}{*}{113} & \multirow{3}{*}{38.6} & $\begin{array}{c}\text { TQM } \\
\text { implemented or }\end{array}$ \\
\hline Implemented but not certified & 1 & 0.3 & & & $\begin{array}{c}\text { in process of } \\
\text { being }\end{array}$ \\
\hline Implemented and certified & 104 & 35.5 & & & implemented \\
\hline Total & & & 293 & 100 & \\
\hline
\end{tabular}

Regarding the level of adoption of TQM, almost $50 \%$ stated that they were not planning to implement it, while almost $12 \%$ stated that they were planning to adopt TQM although they had not yet started the process. The other companies stated that they had already begun the process of implementing TQM. The data are presented with various aggregation levels in Table 2. This alternative to measure the level of adoption of TQM has been used in the literature previously (García-Bernal \& García-Casarejos, 2014). Regarding the recognition or certifications linked to quality management, around $40 \%$ of the companies have this. Specifically, approximately $20 \%$ are certified in ISO 9001 and just under $3 \%$ are certified in ISO 14001. It is worth mentioning that there is a relatively high percentage of companies (15\%) certified in versions of ISO that are now obsolete (ISO 9000 and/or ISO 14000). Concerning membership of 
associations related to quality (for example the Excellence in Management Club, the Spanish Association for Quality, 400 Company Club of Aragon) only just $2 \%$ responded affirmatively.

\section{Expectations of improvement in performance indicators as a result of adopting TQM}

To measure managers' expectations of improvements in business performance as a result of TQM, before it is adopted, the following question was included in the questionnaire: Expectations of the impact of TQM (ex-ante assessment): Please indicate, on a scale of 1 to 10, your expectations of the impact of TQM, before implementation, on the improvement of each of the aspects included in the following table (1 equals no improvement at all, 10 equals highly significant improvement).

The table contained the following aspects: 'Reducing overall costs', 'Reducing production times', 'Increasing company productivity', 'Maintaining current business', 'Increasing earnings', 'Improving your competitive position in markets', 'Improving customer satisfaction', 'Improving employee satisfaction', 'Reducing levels of waste generated', 'Reducing the incidents that have a negative effect on the environment', 'Improving supplier satisfaction', 'Improving the satisfaction of public administrations', 'Improving the community's satisfaction' and 'Improving the satisfaction of non-profit organizations and other activists'.

\section{Empirical Results}

Table 3. Results of the analysis of variance (ANOVA) and Duncan's Test. Source: Own Elaboration

\begin{tabular}{|c|c|c|c|c|c|}
\hline Variables & $\begin{array}{l}\text { Not planning to } \\
\text { implement TQM } \\
\text { (Group 1) }\end{array}$ & $\begin{array}{c}\text { Planning to } \\
\text { implement TQM } \\
\text { but not begun } \\
\text { (Group 2) }\end{array}$ & $\begin{array}{l}\text { TQM implemented or in } \\
\text { process of being } \\
\text { implemented } \\
\text { (Group 3) }\end{array}$ & $\mathbf{F}$ & Duncan's Test \\
\hline Maintaining current business & 3.09 & 5.1 & 6.05 & $81.57^{* * *}$ & $\begin{array}{l}1-2^{* * *} \\
1-3^{* * *} \\
2-3^{* * *}\end{array}$ \\
\hline Increasing earnings & 3.17 & 5.00 & 6.00 & $86.93^{* * *}$ & $\begin{array}{l}1-2^{* * *} \\
1-3^{* * *} \\
2-3^{* * *}\end{array}$ \\
\hline $\begin{array}{l}\text { Improving competitive position } \\
\text { in markets }\end{array}$ & 3.61 & 5.59 & 6.42 & $75.87 * * *$ & $\begin{array}{l}1-2^{* * *} \\
1-3 * * * \\
2-3^{* * *}\end{array}$ \\
\hline Improving customer satisfaction & 4.05 & 5.63 & 6.64 & $76.75^{* * *}$ & $\begin{array}{l}1-2 * * * \\
1-3 * * * \\
2-3 * * *\end{array}$ \\
\hline Improving employee satisfaction & 2.70 & 4.06 & 5.21 & $57.34 * * *$ & $\begin{array}{l}1-2^{* * *} \\
1-3^{* * *} \\
2-3^{* * *}\end{array}$ \\
\hline Reducing waste levels generated & 3.14 & 4.41 & 5.39 & $61.92^{* * *}$ & $\begin{array}{l}1-2^{* * *} \\
1-3^{* * *} \\
2-3^{* * *}\end{array}$ \\
\hline $\begin{array}{l}\text { Reducing incidents with negative } \\
\text { effect on environment }\end{array}$ & 3.37 & 4.50 & 5.78 & $48.02 * * *$ & $\begin{array}{l}1-2 * * * \\
1-3 * * * \\
2-3 * * * \\
\end{array}$ \\
\hline Reducing overall costs & 3.32 & 4.73 & 5.22 & $56.60 * * *$ & $\begin{array}{l}1-2^{* * *} \\
1-3^{* * *}\end{array}$ \\
\hline Reducing production times & 2.81 & 4.61 & 4.93 & $52.42^{* * *}$ & $\begin{array}{l}1-2^{* * *} \\
1-3^{* * *}\end{array}$ \\
\hline Increasing productivity & 3.04 & 5.35 & 5.99 & $92.67^{* * *}$ & $\begin{array}{l}1-2^{* * *} \\
1-3^{* * *}\end{array}$ \\
\hline Improving supplier satisfaction & 2.85 & 4.37 & 5.09 & $61.77^{* * *}$ & $\begin{array}{l}1-2^{* * *} \\
1-3^{* * *}\end{array}$ \\
\hline $\begin{array}{l}\text { Improving the satisfaction of } \\
\text { public administrations } \\
\text { Improving the satisfaction of the } \\
\text { community }\end{array}$ & 3.71 & 4.92 & $\begin{array}{l}6.00 \\
5.88\end{array}$ & $\begin{array}{l}23.84 * * * \\
14.49 * * *\end{array}$ & $\begin{array}{l}1-2 * * * \\
1-3 * * * \\
1-2 * * * \\
1-3 * * *\end{array}$ \\
\hline $\begin{array}{l}\text { Improving the satisfaction of } \\
\text { NPOS \& other activists }\end{array}$ & 2.94 & 4.00 & 4.12 & $6.37 * *$ & \\
\hline
\end{tabular}

An analysis of variance (ANOVA) was conducted to test the proposed hypotheses and see if there are significant differences in the managers' expectations concerning improvements in performance as a result of TQM, between the different groups of companies based on their level of adoption of TQM (Not planning to implement TQM, Planning to implement TQM but not begun, TQM implemented or in process of being implemented). The (post-hoc) Duncan's test was also used to identify significant differences in expectations between specific groups. Table 3 synthesizes the main results. 
The mean values of the expectations of company managers that have started to adopt TQM are higher than those of the companies that are planning to adopt TQM but have not started the process, and the latter, in turn, are higher than the mean values of the companies that are not planning to adopt TQM. In turn, the highest absolute values are observed in the indicators of customer satisfaction and of improvement in the company's competitive position in markets. The expectations of improvement in employee satisfaction are considerably less than those connected with customers. Independently of the higher or lower absolute values obtained in each of the indicators, there are significant differences in the mean values between the three groups of companies in their expectations of maintaining current business, increasing their earnings, improving their competitive position, improving customer satisfaction, improving employee satisfaction, reducing the waste levels generated and reducing the incidents that have a negative effect on the environment. This confirms hypotheses $4,5,6,7,8,10$ and 11.

In certain aspects, there are only significant differences between the group of companies that is not planning to adopt TQM and the other groups. Specifically, these aspects are the decrease in overall costs, decrease in production times, increases in productivity, improvement in supplier satisfaction, improvement in the satisfaction of public administrations, and improvement in the satisfaction of the community. This confirms hypotheses 1, 2, 3, 9, 12 and 13 , although only partially. Finally, there are no significant differences in the mean values between the three groups of companies in their expectations of improving the satisfaction of non-profit organizations and other activists. Therefore, hypothesis 14 is rejected. Figure 3 synthesizes the testing of the proposed hypotheses.

Figure 3. Factors determining the Level of Adoption of TQM. Source: Own Elaboration

Non-financial groups

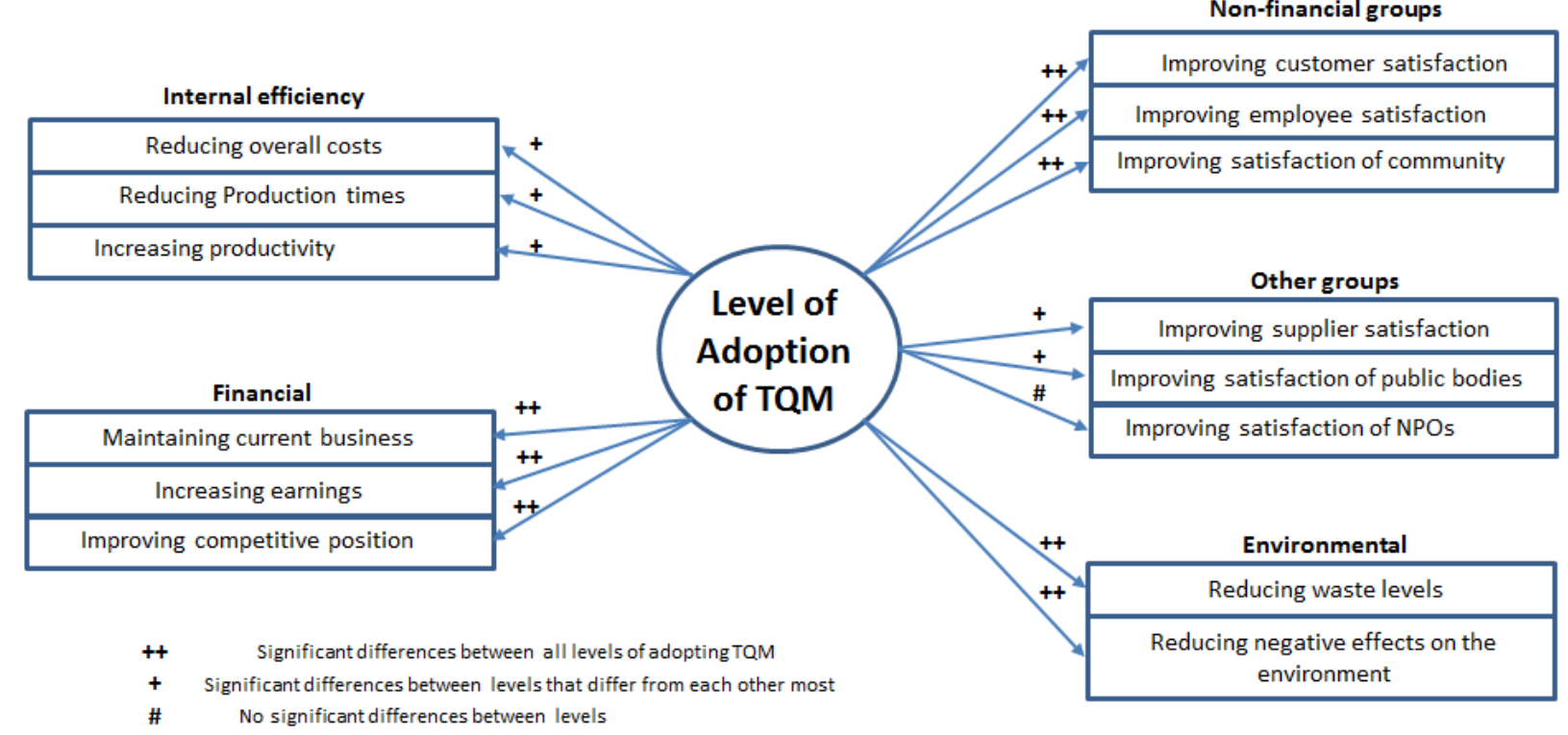

Discussion and conclusions

Although the empirical evidence seems to support the existence of a positive relationship between adopting TQM and improved business performance, the use of TQM among companies is unequal. The specialized literature hardly analyzes why some companies decide to adopt TQM and others do not.

One of this paper's contributions is discovering that managers' expectations of improvements in several business performance indicators do not have the same relevance when deciding to start the implementation process of TQM, since financial and environmental aspects, as well as aspects related to customer and employee satisfaction, are determinants to explain the unequal implementation of TQM in the business sector. However expectations of other indicators, which might at first seem equally important, such as those relating to aspects of internal efficiency, satisfaction of suppliers, public administrations or the community, do not appear as determining factors to explain the various levels of adoption of TQM.

Furthermore, the results of this research allow us to conclude that the managers' expectations of the capacity of TQM to improve business performance effectively condition their level of adoption. Company managers that do not plan to implement TQM have, in general, lower expectations of the capacity of TQM to improve business performance, while 
the expectations of improvement of company managers that have already opted to adopt TQM are significantly higher. The managers of companies that are planning to adopt TQM in the future, but have not yet started the implementation process, are in the middle ground.

Regarding the specific business performance indicators analyzed, except for the improvement in the level of satisfaction of non-profit organizations and other activists, managers' expectations in the other performance improvement indicators causes some companies not to plan to implement TQM in the future, since their mean values are significantly less than those of companies that are planning to adopt TQM, whether they have started the process or not.

Nevertheless, within companies that have decided to adopt TQM, only some specific business performance indicators cause some companies to opt to start the implementation process and others to still delay implementing it. The specific performance indicators are maintaining current business, increasing earnings, improving the competitive position, improving customer satisfaction, improving employee satisfaction, reducing the waste levels generated and reducing the incidents that have a negative effect on the environment. In short, all the business performance aspects that encompass the interests of financial groups (shareholders or business owners), indicators of non-financial groups, such as customers or employees, and indicators directly related to environmental aspects are determining factors. This result is congruent with the new characteristics in which construction companies perform their business, since there has been a considerable increase in environmental and waste management regulations that are an obligatory requirement in recent years. The search for higher levels of satisfaction among customers and the defense of the company owners' or shareholders' interests are the main reasons for adopting organizational innovations such as TQM. The results of Delgado-Hernandez \& Aspinwall (2008) point towards this direction when they confirm that as a result of adopting TQM, companies in the UK construction sector have improved their customers' levels of satisfaction. The lower relative value obtained in the expectation of improvement in employee satisfaction could be indicating that managers continue to have a hierarchical concept of employment relations. This would manifest the managers' lack of conviction in these improvements resulting from management standardization mechanisms.

However, within the companies that are planning to adopt TQM, business performance aspects relating to a decrease in overall costs, a decrease in production times, increases in productivity, improvement in supplier satisfaction, improvement in the satisfaction of public administrations, and improvement in the satisfaction of the community are not determinants in the decision to begin the process of implementing TQM or not. In other words, for companies that are planning to adopt TQM, the aspects directly related to internal efficiency and the satisfaction of non-financial groups, such as suppliers, public administrations and the community, are not determinants in differentiating between companies that have started the process of adopting or implementing TQM and those that have not. The peculiarities of the construction sector might account for these results, since over $60 \%$ of the final cost of the product is for the supply of materials. That is why the companies strive to reduce these purchase prices, or even reduce the pressure of debt in their income statements; consequently, the relative search for other savings on costs might be relegated to the background. Proof of this is that the rate of increase in costs (excluding personnel costs) in the 2005-2009 period was $19.63 \%$ (data obtained from the 'Cost index of the construction sector 2005 database', of the Ministry of Development of Spain). Furthermore, suppliers as a group that is not determinant for the adoption of TQM could be explained by the extent to which the relationship with subcontractors and with suppliers of materials is conditioned by a low-price strategy.

Finally, the fact of higher or lower expectations of an improvement in the level of satisfaction of non-profit organizations and other activists is not an element that conditions the level of adoption of TQM in the business environment. The main business implication arising from the research highlights the role that training could have on the increase in competitiveness in the sector. The training of managers in the construction sector in TQM systems and other organizational innovations would involve more knowledge of them and of the improvements that can result from adopting them. This would translate into a higher level of implementation of TQM within the sector and, therefore, more utilization of the potential for efficiency and competitiveness associated with these management tools.

The research presents a series of limitations arising mainly from the characteristics of the sample analyzed. They include the fact that the sample of companies studied is located in the Autonomous Community of Aragon; future lines of research should, therefore, expand on the geographical scope of the study. The influence of some factors such as size or sector of activity could be considered in the future. Also, more complex analytical instruments could be useful for more additional analysis. Despite these limitations, the results of the study make it possible to advance in the identification of determining factors in the process of construction companies' implementation of TQM based on a management perspective. 
Adam, E. E. (1994). Alternative quality improvement practices and organization performance. Journal of Operations Management, 12(1), 27-44. http://doi.org/10.1016/0272-6963(94)90004-3

Anderson, J. C., Rungtusanatham, M., Schroeder, R. G., \& Devaraj, S. (1995). A Path Analytic Model of a Theory of Quality Management Underlying the Deming Management Method: Preliminary Empirical Findings. Decision Sciences, 26(5), 637-658. http://doi.org/10.1111/j.15405915.1995.tb01444.x

Arriagada, R., \& Alarcon, L. (2013). Estilos de organización y acciones clave que facilitan la gestión de conocimiento en un proyecto de construcción. Revista de La Construcción, 12(2), 4-15. http://doi.org/10.4067/S0718-915X2012000100002

Bou-Llusar, J. C., Escrig-Tena, A. B., Roca-Puig, V., \& Beltrán-Martín, I. (2009). An empirical assessment of the EFQM Excellence Model: Evaluation as a TQM framework relative to the MBNQA Model. Journal of Operations Management, 27(1), 1-22. http://doi.org/10.1016/j.jom.2008.04.001

Corredor, P., \& Goñi, S. (2011). TQM and performance: Is the relationship so obvious? Journal of Business Research, 64(8), 830-838. http://doi.org/10.1016/j.jbusres.2010.10.002

Delgado-Hernandez, D. J., \& Aspinwall, E. (2008). Quality management case studies in the UK construction industry. Total Quality Management \& Business Excellence, 19(9), 919-938. http://doi.org/10.1080/14783360802224545

Duh, R., Hsu, A., \& Huang, P. (2012). Determinants and performance effect of TQM practices: An integrated model approach. Total Quality Management \& Business Excellence, 23(5/6), 689-701. http://doi.org/10.1080/14783363.2012.669555

Escrig-Tena, A. B., \& Bou-Llusar, J. C. (2005). A model for evaluating organizational competencies: An application in the context of a Quality Management initiative. Decision Sciences, 36(2), 221-257. http://doi.org/10.1111/j.1540-5414.2005.00072.x

Flynn, B. B., Sakakibara, S., \& Schroeder, R. G. (1995). Relationship Between JIT and TQM: Practices and Performance. The Academy of Management Journal, 38(5), 1325-1360.

García-Bernal, J., \& García-Casarejos, N. (2014). Economic analysis of TQM adoption in the construction sector. Total Quality Management \& Business Excellence, 25(3-4), 209-221. http://doi.org/10.1080/14783363.2012.728848

García-Bernal, J., \& Ramírez-Alesón, M. (2010). Increasing the Organisational Performance Benefits of TQM: an Approach Based on Organisational Design. Total Quality Management \& Business Excellence, 21(February 2015), 363-382. http://doi.org/10.1080/14783361003606548

Hendricks, K. B., \& Singhal, V. R. (2001). The Long-Run Stock Price Performance of Firms with Effective TQM Programs. Management Science, 47(3), 359-368. http://doi.org/10.1287/mnsc.47.3.359.9773

Instituto Aragonés de Empleo. (2008). Estudio del sector de la construcción, perspectivas de futuro. Zaragoza.

ISSLA. (2013). Siniestralidad Laboral. Comunidad Autónoma de Aragón.

Lai, K., \& Cheng, T. C. E. (2003). Initiatives and outcomes of quality management implementation across industries. Omega, 31(2), $141-154$. http://doi.org/http://dx.doi.org/10.1016/\$0305-0483(03)00021-5

Mann, R., Adebanjo, D., Laosirihongthong, T., \& Punnakitikashem, P. (2011). Awareness and Impact of Business Excellence in Asia. Total Quality Management \& Business Excellence, 22(11), 1237-1258. http://doi.org/10.1080/14783363.2011.624772

Powell, T. C. (1995). Total quality management as competitive advantage: A review and empirical study. Strategic Management Journal, 16(1), 1537. http://doi.org/10.1002/smj.4250160105

Rao, S. S., Solis, L. E., \& Raghunathan, T. S. (1999). A framework for international quality management research: Development and validation of a measurement instrument. Total Quality Management, 10(7), 1047-1075. http://doi.org/10.1080/0954412997226

Rubio-Andrada, L., Alonso-Almeida, M. D. M., \& Rodríguez-Antón, J. M. (2011). Motivations and impacts in the firm and stakeholders of quality certification: Evidence from small- and medium-sized service enterprises. Total Quality Management \& Business Excellence, 22 (8), 833-852. http://doi.org/10.1080/14783363.2011.593858

Samson, D., \& Ford, S. (2000). Manufacturing practices and performance : Comparisons between Australia and New Zealand. International Journal of Production Economics, 65(3), 243-255. http://doi.org/10.1016/S0925-5273(99)00076-6

Sila, I., \& Ebrahimpour, M. (2005). Critical linkages among TQM factors and business results. International Journal of Operations \& Production Management, 25(11), 1123-1155. http://doi.org/10.1108/01443570510626925

Taylor, W. a., \& Wright, G. H. (2006). The contribution of measurement and information infrastructure to TQM success. Omega, 34(4), 372-384. http://doi.org/10.1016/j.omega.2004.12.003

Wilson, D. D., \& Collier, D. a. (2000). An Empirical Investigation of the Malcolm Baldrige National Quality Award Causal Model. Decision Sciences, 31(2), 361-383. http://doi.org/10.1111/j.1540-5915.2000.tb01627.x

Wruck, K. H., \& Jensen, M. C. (1994). Science, specific knowledge, and total quality management. Journal of Accounting and Economics, 18(3), 247287. http://doi.org/10.1016/0165-4101(94)90023-X 